\title{
Thievery in rainforest fungus-growing ants: interspecific assault on culturing material at nest entrance
}

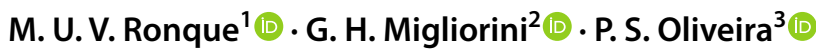

Received: 15 March 2018 / Revised: 21 May 2018 / Accepted: 22 May 2018 / Published online: 5 June 2018

(c) International Union for the Study of Social Insects (IUSSI) 2018

\begin{abstract}
Cleptobiosis in social insects refers to a relationship in which members of a species rob food resources, or other valuable items, from members of the same or a different species. Here, we report and document in field videos the first case of cleptobiosis in fungus-growing ants (Atta group) from a coastal, Brazilian Atlantic rainforest. Workers of Mycetarotes parallelus roam near the nest and foraging paths of Mycetophylax morschi and attack loaded returning foragers of M. morschi, from which they rob cultivating material for the fungus garden. Typically, a robbing Mycetarotes stops a loaded returning Mycetophylax, vigorously pulls away the fecal item from the forager's mandibles, and brings the robbed item to its nearby nest. In our observations, all robbed items consisted of arthropod feces, the most common culturing material used by M. parallelus. Robbing behavior is considered a form of interference action to obtain essential resources needed by ant colonies to cultivate the symbiont fungus. Cleptobiosis between fungus-growing ants may increase colony contamination, affect foraging and intracolonial behavior, as well as associated microbiota, with possible effects on the symbiont fungus. The long-term effects of this unusual behavior, and associated costs and benefits for the species involved, clearly deserve further investigation.
\end{abstract}

Keywords Ant behavior $\cdot$ Fungus-growing ants $\cdot$ Interference competition $\cdot$ Theft $\cdot$ Atlantic rainforest

\section{Introduction}

Among social insects, thievery of food items, nesting material, brood, or other valuable items is known as cleptobiosis and can occur among individuals of the same or of different species that do not nest in close association (Breed et al. 2012). This ecological relationship is a form of interference competition, and may be an important strategy for obtaining valuable resources (Hölldobler 1986). Cleptobiosis has been

Electronic supplementary material The online version of this article (https://doi.org/10.1007/s00040-018-0632-9) contains supplementary material, which is available to authorized users.

P. S. Oliveira

pso@unicamp.br

1 Programa de Pós-Graduação em Ecologia, Instituto de Biologia, Universidade Estadual de Campinas, C.P. 6109, Campinas, SP 13083-862, Brazil

2 Programa de Pós-Graduação em Biologia Animal, Universidade Estadual Paulista "Júlio de Mesquita Filho", São José do Rio Preto, SP, Brazil

3 Departamento de Biologia Animal, Universidade Estadual de Campinas, C.P. 6109, Campinas, SP 13083-862, Brazil reported in social insects such as ants, bees and wasps, as well as in other arthropod groups such as spiders and thrips (Breed et al. 2012; and included references). Several cases of inter and intraspecific food robbing have been reported among ant species. For instance, Hölldobler (1986) observed that Myrmecocystus mimicus robs prey from Pogonomyrmex desertorum and $P$. maricopa; Perfecto and Vandermeer (1993) reported Ectatomma ruidum stealing food items from Pheidole radoszkowskii; Yamaguchi (1995) observed seed stealing between neighboring colonies of Messor aciculatus; and Richard et al. (2004) demonstrated for the first time sugary food robbing by Crematogaster limata from Ectatomma tuberculatum.

Here, we report the first case of thievery of culturing material (cleptobiosis) involving two species of fungusgrowing ants, Mycetophylax morschi (Emery) and Mycetarotes parallelus (Emery), in a coastal, sand-based ("restinga") Atlantic rainforest of Brazil. Mycetophylax morschi and Mycetarotes parallelus belong to the monophyletic Neotropical Attina subtribe (Formicidae: Myrmicinae: Attini). Both species have obligatory mutualisms with the symbiotic fungi cultivated inside their nests, which serve as food source for the whole colony (Hölldobler and Wilson 2011). 
Mycetarotes parallelus occurs from central and southeast Brazil (Atlantic rainforest, Cerrado savanna, and Amazonia) to northern Argentina (Mayhé-Nunes and Brandão 2006). Mycetophylax morschi occurs exclusively along the Atlantic coast of South America (Klingenberg and Brandão 2009). Henceforth, the two ant species are each referred to by the genus only.

\section{Materials and methods}

Observations were carried out in October 2016 in Atlantic rainforest at the Parque Estadual Serra do Mar (Núcleo Picinguaba, $23^{\circ} 21^{\prime} 28^{\prime \prime} \mathrm{S}, 44^{\circ} 51^{\prime} 00^{\prime \prime} \mathrm{W}$ ), near Ubatuba, São Paulo, Southeast Brazil. Records of interspecific thievery are based on $8 \mathrm{~h}$ of observation involving two neighboring nests of Mycetarotes and Mycetophylax (55 cm apart). The videos were recorded using Sony Handycam DCR-SR85.

In previous observations in the same area (April-June 2015), we monitored the foraging activity in each of three colonies of Mycetarotes and Mycetophylax, totaling $30 \mathrm{~h}$ of observation for each species. The resources collected by Mycetarotes and Mycetophylax to cultivate the fungus garden were removed from returning foragers and preserved in $100 \%$ ethanol for identification. All observations and interaction events between the two species were made between 09:00 a.m. and 03:00 p.m., at the peak of ant activity.

\section{Results and discussion}

Workers of Mycetarotes roam near the nest and foraging grounds of Mycetophylax and attack returning foragers. Ant robbers intercept laden Mycetophylax workers on their way back to the nest, or at the very vicinity $(10-20 \mathrm{~cm})$ of the nest entrance (see video ESM1 in supplementary material).
We recorded seven attempts by Mycetarotes robbers towards Mycetophylax foragers bringing in arthropod feces for fungus culturing. Typically, a robbing Mycetarotes stops a loaded returning Mycetophylax, vigorously pulls away the fecal item from the forager's mandibles (Fig. 1), and brings the robbed item to its nearby nest (see video ESM2 in supplementary material). Upon assault, loaded Mycetophylax foragers may grasp the resource tightly and win the item after fighting with robbing ants for up to $10 \mathrm{~s}$ (two occasions). Three Mycetophylax workers were once seen helping an intercepted nestmate by biting the assaulting Mycetarotes, which was chased away without robbing the item. Probably due to their larger size (Mycetarotes $\approx 2.8 \mathrm{~mm}$; Mycetophylax $\approx 1.8 \mathrm{~mm}$ ), Mycetarotes workers are often successful at pulling the item loose from Mycetophylax (four occasions). On one occasion, an approaching Mycetarotes walked away after briefly antennating/inspecting a loaded Mycetophylax worker.

In all observed theft incidents, the robbed item was taken directly to the nearby Mycetarotes nest by the assaulting ant (see video ESM2 in supplementary material). After ca. 5 min, a Mycetarotes worker would consistently exit the same nest toward the very location where the robbing event had recently been recorded. Although this observation might suggest persistence of robbing activities by individual workers, as documented in other prey-robbing ants (Hölldobler 1986), further investigation with marked ants is required to confirm this suggestion.

In a field account on the foraging ecology of Mycetophylax and Mycetarotes in the same area, we observed that both species collect vegetable matter (e.g. leaf and wood fragments), arthropod feces, and arthropod carcass to cultivate the symbiotic fungus. Arthropod feces constitute 35 and 50\% of the items collected by Mycetophylax and Mycetarotes, respectively (Fig. 2a). Data from these three Mycetarotes colonies show that, during $8 \mathrm{~h}$ of foraging activity, colonies

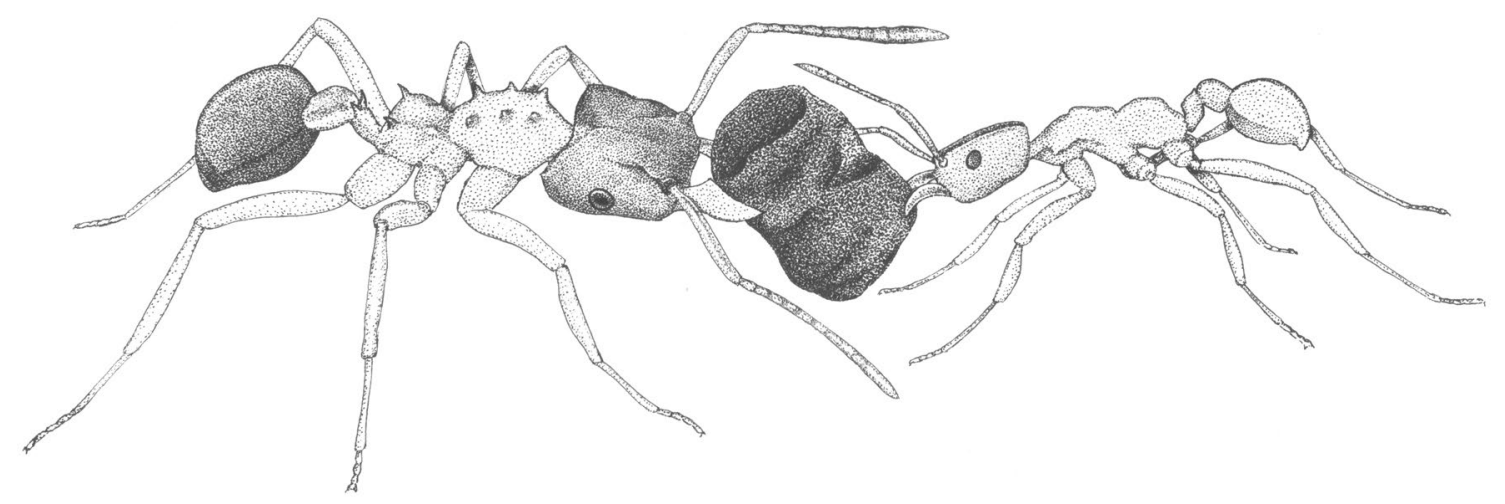

Fig. 1 Schematic drawing of a theft event: a worker of Mycetarotes parallelus (left) pulls a recently-collected fecal item from the mandibles of a returning worker of Mycetophylax morschi. The robbing ant will take the stolen item to its nearby nest as substrate for the fungus garden (see also Fig. 2). Drawing by Luisa Mota 
Fig. 2 a Culturing substrate for mutualistic fungus collected by Mycetarotes parallelus and Mycetophylax morschi in coastal Atlantic rainforest, southeast Brazil. Numbers in parentheses designate quantity of items collected during $30 \mathrm{~h}$ of observation (three colonies per species). b A view of the fungus garden of Mycetarotes parallelus showing worker using arthropod feces (arrow) as culturing substrate. The colony was collected in sandy Atlantic rainforest, southeast Brazil

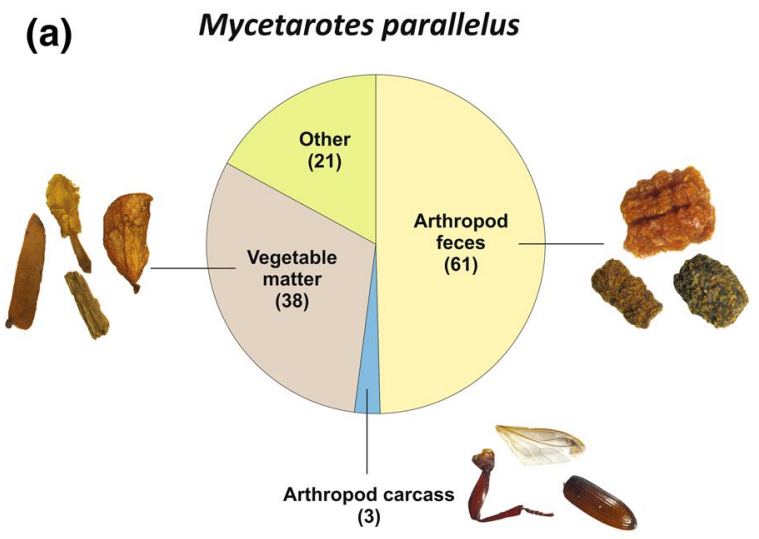

Mycetophylax morschi

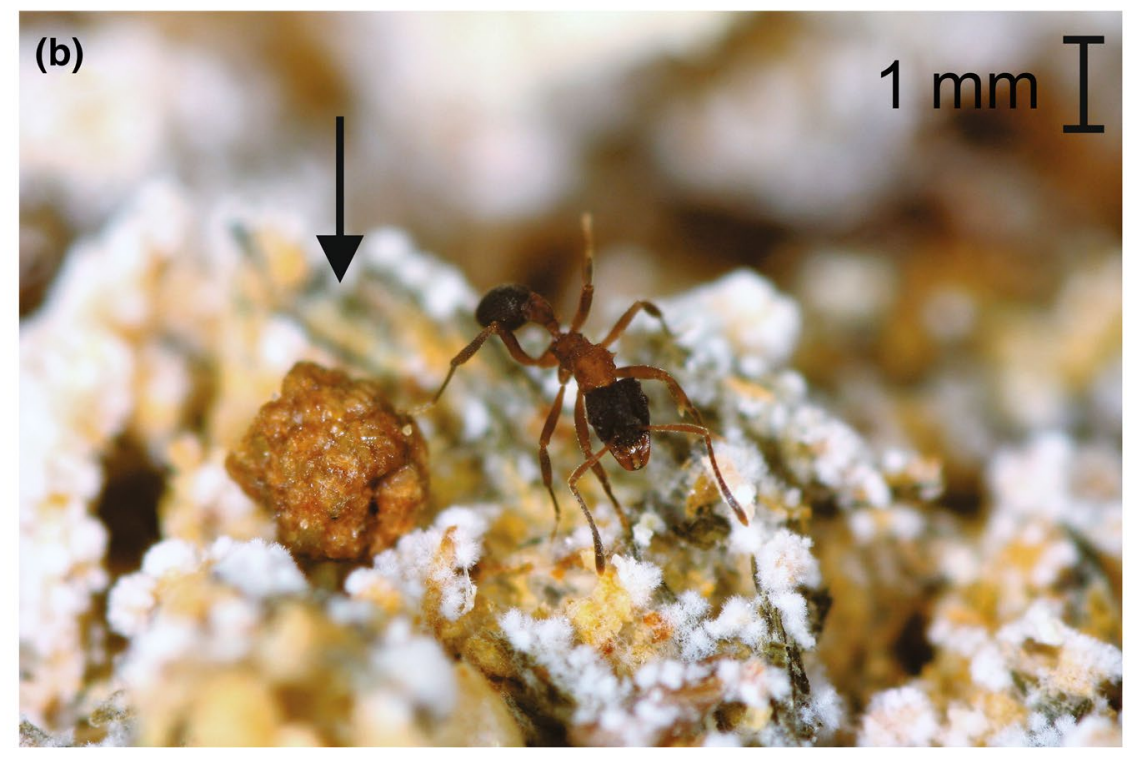

collect on average 16 fecal items $(16.26 \pm 1.66$, mean \pm SD, $\mathrm{N}=3$ ) for fungus culturing. Our records of robbing involving neighboring Mycetarotes and Mycetophylax (four stolen items in $8 \mathrm{~h}$ ) would thus represent nearly $24 \%$ of the fecal items normally collected by Mycetarotes foragers.

Mycetarotes and Mycetophylax are sympatric and have similar preferences for the type of material used for fungus culturing (mainly feces and dead plant fragments, Fig. 2a, b). Although the items stolen by Mycetarotes are not for direct ant feeding, they are essential for the cultivation of the symbiont fungus that feeds the colony (Fig. 2b). Unlike leafcutter ants of the genera Acromyrmex and Atta that use fresh plants (fixed and spatially predictable) to cultivate the symbiont fungus, the fecal pellets used by these two non-leafcutter attines are scattered in the environment and may be hard to find, analogous to animal prey and seeds (see Hölldobler 1986; Yamaguchi 1995). Robbery by Mycetarotes may be advantageous by saving foraging time and reducing predation risk to foragers, thus optimizing fungus and colony growth. The degree to which thievery by Mycetarotes can affect foraging activity and fungus growth in Mycetophylax colonies await further experimental assessment.

Compared to leaf-cutters, the non-leaf-cutter attine ants are less specialized regarding the material collected for fungus culturing (Wirth et al. 2003; Hölldobler and Wilson 2011). They use arthropod feces and carcass, decaying plant material, fallen fruits and seeds as cultivating material, and can be considered opportunistic (Hölldobler and Wilson 2011). The use of fresh plant material by highly selective Atta and Acromyrmex, on the other hand, requires several adaptations of the fungus garden for processing the culturing substrate (Khadempour et al. 2016). The low substrate specificity for fungus culturing may thus have favored cleptobiotic behavior in non-leaf-cutter attines, since the fungus garden can develop on variable surfaces and robbed items have good chances of promoting fungus growth. Indeed, two species of non-leaf-cutter attines-Apterostigma urichii and Cyphomyrmex faunulus - can live in parabiosis and share the same nest and fungus garden without mutual aggression (Sanhudo et al. 2008). This case reinforces the flexibility of the fungus 
regarding the culturing substrate, suggesting behavioral plasticity among species of non-leaf-cutter attines.

Cleptobiotic interactions among ants can increase the risk of contamination and pathogenic diseases between cleptobiont colonies due to their frequent and close contact with one another (Breed et al. 2012). Because Mycetarotes and Mycetophylax workers come in close contact during cleptobiosis, the risk of colony contamination likely increases for both species involved. This could be a critical factor for development of the fungus garden inside their colonies since this symbiosis is susceptible to external contamination, which can lead to death of the fungus and of the entire colony (Currie 2001). Similarly, cases of garden stealing or garden sharing in fungus-growing ants may also result in contamination, leading to pathogen cultivar transfers from one colony to another, as suggested by Adams et al. (2000). Attine ants have diverse bacterial communities associated with their body surface and fungus garden, and some bacteria may protect the ants and the fungus against pathogens (Kost et al. 2007; Mueller et al. 2008). In addition, ant workers of the attine ants keep their fungus free from infection by physically removing invasive microorganisms (Currie 2001). This cleaning behavior is frequently observed in Mycetarotes and Mycetophylax colonies (MUV Ronque, unpublished data). Grooming is thought to have favored the evolutionary success of fungus-farming ants by decreasing the risk of colony death from infection, thus promoting colony growth (Currie 2001). Grooming behavior may be particularly important for the Mycetarotes $\times$ Mycetophylax cleptobiotic interaction, since microorganisms potentially causing diseases from one species to another can be removed by cleaning workers inside the colonies.

The current field account is the first case of cleptobiosis involving thievery of culturing material between species of fungus-growing ants. The long-term effects of this unusual behavior and the costs and benefits for each species clearly need to be investigated in greater detail, with more quantitative data. This report may stimulate interest in the evolution of foraging and intracolonial behavior, as well as on the microbiology (risk of contamination, associated microbiota) of cleptobiont species in the Attina subtribe, and the possible effect of cleptobiosis on the symbiont fungus.

Acknowledgements We thank Edward O. Wilson, Bert Hölldobler, Rainer Wirth and Rodrigo Feitosa for feedback on the manuscript, and Luisa Mota for the drawing. MR and GM were funded by the
Coordenação de Aperfeiçoamento de Pessoal de Nível Superior; PO was supported by the São Paulo Research Foundation (\#2014/23141-1, 2017/16645-1) and the Brazilian Research Council (\#306115/2013-1, 302219/2017-0). Rodrigo Feitosa identified the ants, and the Parque Estadual da Serra do Mar provided logistic support during field work. This study is part of the PhD dissertation of MR at the Programa de Pós-Graduação em Ecologia of the Universidade Estadual de Campinas.

\section{References}

Adams RMM, Mueller UG, Holloway AK, Green AM, Narozniak J (2000) Garden sharing and garden stealing in fungus-growing ants. Naturwissenschaften 87:491-493

Breed MD, Chelsea C, Krasnec MO (2012) Cleptobiosis in social insects. Psyche 2012:1-7

Currie CR (2001) A community of ants, fungi and bacteria: a multilateral approach to studying symbiosis. Annu Rev Microbiol $55: 357-380$

Hölldobler B (1986) Food robbing in ants, a form of interference competition. Oecologia 69:12-15

Hölldobler B, Wilson EO (2011) The leafcutter ants: civilization by instinct. W.W Norton \& Company, New York, pp 157

Khadempour L, Burnum-Johnson KE, Baker ES, Nicora CD, WebbRobertson BM, White RA, Monroe ME, Huang EL, Smith RD, Currie CR (2016) The fungal cultivar of leaf-cutter ants produces specific enzymes in response to different plant substrates. Mol Ecol 25:5795-5805

Klingenberg C, Brandão CRF (2009) Revision of the fungus-growing ant genera Mycetophylax Emery and Paramycetophylax Kusnezov rev. stat., and description of Kalathomyrmex n. gen. (Formicidae: Myrmicinae: Attini). Zootaxa 2052:1-31

Kost C, Lakatos T, Böttcher I, Wolf-Rüdiger A, Redenbach M, Wirth R (2007) Non-specific association between filamentous bacteria and fungus-growing ants. Naturwissenschaften 94:821-828

Mayhé-Nunes AJ, Brandão CRF (2006) Revisionary notes on the fungus-growing ant genus Mycetarotes Emery (Hymenoptera, Formicidae). Rev Bras Entomol 50:463-472

Mueller UG, Debadutta D, Rabeling C, Rodrigues A (2008) Coevolution between attine ants and actinomycete bacteria: a reevaluation. Evolution 62:2894-2912

Perfecto I, Vandermeer JH (1993) Cleptobiosis in the ant Ectatomma ruidum in Nicaragua. Insectes Soc 40:295-299

Richard FJ, Dejean A, Lachaud JP (2004) Sugary food robbing in ants: a case of temporal cleptobiosis. CR Biol 327:509-517

Sanhudo CED, Izzo TJ, Brandão CRF (2008) Parabiosis between basal fungus-growing ants (Formicidae, Attini). Insectes Soc 55:296-300

Wirth W, Herz H, Ryel RJ, Beyschlag W, Hölldobler B (2003) Herbivory of leaf-cutting ants: a case study on Atta colombica in the Tropical Rainforest of Panama. Ecol Stud 164:1-230

Yamaguchi T (1995) Intraspecific competition through food robbing in the harvester ant, Messor aciculatus (Fr. Smith), and its consequences on colony survival. Insectes Soc 42:89-101 